\title{
Methodology to Prove the Quranic Correctness
}

\author{
Tahara Hiroki \\ Jan Academy \\ Corresponding Author: Tahara Hiroki.
}

ABSTRACT: I brainstormedabout the methodology to prove the Quranic correctness i.e. to discover the components of Tahara I function, which advocates that studies by mathematical beauty, of the Quranic contents, and of the prophets are good to prove the Quranic correctness.

KEYWORDS: Quran, Quran and Science, Tahara I Function, Tahara's Definition, Methodology, Mathematical Beauty, Quranic Contents, Prophets.

Date of Submission: 17-09-2019

Date of acceptance: 05-10-2019

\section{INTRODUCTION}

Quran is correct if and only if Tahara I function exits uniquely (Tahara, 2019) according to Tahara's definition. Tahara I function is defined as I as follows:

$$
I=\sum i\left(i: 2^{\left[Q_{\text {S }}\right]} \times 2^{[\text {T.P. }]} \rightarrow 2^{[\text {[.P. }]} \wedge i: \text { meaningful }\right)
$$

and its components are defined as $i$ as follows:

$$
i: 2^{[\mathrm{Q} \text {.S. }]} \times 2^{[\text {[T.P. }]} \longrightarrow 2^{[\text {[T.P. }]} \wedge i: \text { meaningful }
$$

Therefore, people who want to prove the Quranic correctness have to brainstorm in order to discover more than one component of Tahara I function according. As a scientific fundamentalist which is one of Quranic believers (they are usually called muslims(Murray et al., 1933), especially Quranists however I don't call them muslim because of several reasons.), I will brainstorm about the methodology to prove the Quranic correctness i.e. to discover the components of Tahara I function.

\section{DISCUSSION}

I think there are at least three kinds of good way to prove the Quranic correctness. Below I will explain them.

\section{Studies by Mathematical Beauty}

It is obvious that Tahara I function depends on 'meaningful'ness and it includes mathematical beauty. In addition to this, mathematical beauty is often useful to solve important issues of near-to-God i.e. world-base academic field i.e. Logic, Mathematics and Physics (Dirac, 1940) (Wigner, 1960). According to Watt (1962), from muslim religious view, the Quran is one of the revelations, which is only exactly correct one i.e. the Quran is near-to-God. Therefore, we might ought to try to discover the components of Tahara I function with us inspired by mathematical beauty.

\section{Studies of the Quranic Contents}

Traditionally, Quranic contents have been studied in order to prove the Quranic correctness (Fakhry, 2004). This way of studies is being conducted even in recent years (Ali, 2015) as interpreting Quranic sentences as expressions of truth (Wahid, 2015). I think the traditional way can suggest many examples of the results of the components of Tahara I function and it might be keys to discover the components of Tahara I function.

\section{Studies of the Revelation Mediums}

From religious view, revelations including Quran are send through messengers (Wheeler, 1962). Therefore, if it is true, we can consider thateach of them has each role as a revelation medium and it is not strange for me to think that we might be able to find something good to prove the Quranic correctness by studies of them i.e. prophets.

\section{CONCLUSION}

As I wrote above, I think that studies by mathematical beauty, of the Quranic content, and of the prophets are good to prove the Quranic correctness.It is important that we have to brainstorm no matter what great scholars such as Al-Ash'ari (Madelung, 2000) or Al-Maturidi (Matsuyama, 2013) said, I think. 


\section{REFERENCES}

[1]. Tahara, H. (2019). The Mathematical Expressions of Quranic Exegeses and the Mathematical Definition of the Quranic Correctness. OSF Preprints, 6dsxb

[2]. Tahara, H. (2019). Erratum: OSF Preprints 6dsxb. OSF Preprints,q4sw3.

[3]. Murray, James Augustus Henry, et al. (1933). The Oxford English Dictionary.

[4]. Dirac, Paul Adrian Maurice. (1940). XI.-The Relation between Mathematics and Physics. Proceedings of the Royal Society of Edinburgh,59: 122-129.

[5]. Wigner, Eugene. (1960). The Unreasonable Effectiveness of Mathematics in the Natural Sciences.

[6]. Watt, William Montgomery. (1962) Islamic Theology and Philosophy. Routledge.

[7]. Fakhry, Majid. (2004). A History of Islamic Philosophy. Columbia University Press.

[8]. Ali, Maulana Muhammad. (2015). Holy Quran. Ahmadiyya Anjuman Ishaat Islam Lahore USA.

[9]. Wahid, Pallacken Abdul. (2015). The Quran: Scientific Exegesis.

[10]. Wheeler, Brannon (Ed.). (2002).Prophets in the Quran: An introduction to the Quran and Muslim exegesis. A\&C Black.

[11]. Madelung, Wiferd. (2000). Abu al-Mu‘īn al-Nasafī and Ash'arī Theology.The Sultan's Turret: Studies in Persian and Turkish Culture. Vol. II. ed. Carole Hillenbrand, 318-330. Leiden: Brill.

[12]. Matsuyama, Yohei. (2013).Notes on Diverse Aspects of Studies on Maturidism (JAPANESE:マートゥリーディー学派研究の諸 側面). Annals of Japan Association for Middle East Studies. 29.1: 145-159.

Tahara Hiroki" Methodology to Prove the Quranic Correctness" International Journal of Humanities and Social Science Invention (IJHSSI), vol. 08, no. 10, 2019, pp. 01-02 